\title{
Correlation of Expression of ER, PR with the onset age, histopathological grading, size of tumor and metastatic behavior of invasive duct cell carcinoma breast
}

\author{
Gupta $\mathbf{M}^{1}$, Pal $S^{2}$ \\ ${ }^{1}$ Dr Mohan Lal Gupta, Associate Professor, Department of Pathology Geetanjali Medical College and Hospital Udaipur, \\ Rajasthan, India, ${ }^{2}$ Dr Shweta Pal, Senior Resident, All India Institute of Medical Sciences, Rishikesh, Uttarakhand, India.
}

Address for Correspondence: Dr. M.L.Gupta, B11A, Navlok, Navratna Complex, Udaipur, India. Email: drguptaml@yahoo.in

\begin{abstract}
Carcinoma breast is a heterogeneous malignancy with distinct age of onset pattern. Age specific incidence profile of breast carcinoma shows exponential rise until menopause and then slow after menopause. Largely early onset breast carcinoma represents inherited cause and late onset breast cancer following extended exposure to cancer promoters. Expression of ER shows gradual increase beginning in $3^{\text {rd }}$ decade to a plateau by 6 th decade. The present study is aimed at the correlation of expression of ER, PR with the onset of age of breast cancer, histopathological grading, size of tor and metastatic behavior. Material and Method: The study was carried out in 80 cases of invasive duct cell carcinoma. Clinicopathological findings, histopathological grading and immunohistochemistry for ER and PR expression were performed. Result and Conclusion: Majority cases (85\%) of invasive duct cell carcinoma fall in 31 to 60 years of age group. Most of the patients show more than $2 \mathrm{cms}$ size (90\%). Majority of the patients fall in histopathological grade II (67.5\%) followed by grade I (27.5\%). Lymph node metastasis was seen in $45 \%$ cases in all grades. ER and PR expression show declining trend with age of onset of breast carcinoma. It reflects dysregulated ER and PR expression which contribute to the breast carcinoma etiology. Loss of ER expression result in to distinct age of onset pattern, therefore early onset breast cancer may be benefitted by hormone therapy. Metastatic behavior is independent of ER and PR expression.
\end{abstract}

Key words: Breast cancer, correlation of expression of ER, PR, Clinicopathological findings.

\section{Introduction}

Carcinoma breast is the most common cancer in women and $2^{\text {nd }}$ leading cause of death [1]. Breast carcinoma show a distinct age of onset pattern with exponential rise until menopause and then gradual rise after menopause [2]. Estrogen Receptor expression in normal breast shows gradual rise beginning in $3^{\text {rd }}$ decade to plateau by $6^{\text {th }}$ decade. Expression of Progesterone Receptors does not show aging effect but show monthly changes within each cycle [3]. Many pathological features have prognostic significance in the management of breast carcinoma including age, tumor size, histopathological types, grading, lymph node metastatic status, estrogen and progesterone receptor

Manuscript received $2^{\text {nd }}$ May 2016

Reviewed: $12^{\text {th }}$ May 2016

Author Corrected: $26^{\text {th }}$ May 2016

Accepted for Publication $11^{\text {th }}$ June 2016 expression, tumor suppression genes and oncogenes. Prognosis of the breast cancer becomes worse if tumor show high grade, metastasis, and certain types of beast carcinoma like medullary or lobular carcinoma. Expression of hormone receptors like estrogen, progesterone, Her-2/neu, and BRCA gene are very important from prognostic point of view. ER, PR and Her-2/neu are very useful for treatment and assessment of prognosis in breast carcinoma. Determination of ER and PR status on biopsy specimen is advocated as a standard practice [4].

The present study is aimed at the correlation of expression of ER, PR with onset age, histopathological grading, sizes of tumor and metastatic behavior of breast carcinoma. 


\section{Material and method}

The present study comprised of 80 cases of Invasive duct cell carcinoma during the year 2013 to 2014 at Gupta Clinical Lab Udaipur. Repeat Udaipur deleted.

Clinical features like age, duration of symptoms, tumor size, margins of surgical specimen, lymph node status were noted. Detailed gross examination was done of each case. Routine Hematoxylin Eosin stained histopathological diagnosis and grading was done in accordance with modified Bloom Richardson grading system. Immunohistochemistry of paraffin embedded tissue sections were prepared and interpreted at Oncquest Laboratories Ltd. New Delhi. ER and PR positive cells were counted and intensity of staining was recorded using Polymer based detection system. Interpretation was based on American Society of Clinical oncology / College of American pathologists' guidelines recommendations for immunohistochemical testing of estrogen and progesterone receptors in breast cancer 2010. Antibodies used are ER-SP1 (Neomarkers) PR-SP (Neomarkers).

\section{Result}

In the present study a total of 80 cases of invasive duct cell carcinoma of breast range from 30 years to 99 years. Majority of cases falls between 30 to 60 years of age group (85\%) as shown in table 1, with peak age incidence of 51 to 60 years age group. Before the age of 30 years and after 70 years incidences are very low.

Most of tumors were of more than $2 \mathrm{cms}$ size (92\%) as shown in table 2. Majority of cases falls in BR grade II (67.5\%) followed by BR grade I (27.5\%). Only 5\% patients belong to Grade III category as shown in Table 1. Axillary lymph node metastasis of tumor cells was seen in $44 \%$ cases rest $56 \%$ patients did not show metastasis as shown in Table 2.

Table-1: Distribution of Age and Histopathological grade of Invasive Duct cell carcinoma (Bloom Richardson Grade)

\begin{tabular}{|c|c|c|c|c|c|}
\hline Age group & $\begin{array}{c}\text { No. of } \\
\text { patients }\end{array}$ & Percentage & IDC Grade I & IDC Grade II & IDC Grade III \\
\hline $1-30$ years & 2 & $2.5 \%$ & 2 & 0 & 0 \\
\hline $31-40$ years & 18 & $22.5 \%$ & 4 & 14 & 0 \\
\hline $41-50$ years & 20 & $25 \%$ & 8 & 10 & 2 \\
\hline $51-60$ years & 30 & $37.5 \%$ & 6 & 24 & 0 \\
\hline $61-70$ years & 8 & $10 \%$ & 0 & 6 & 2 \\
\hline 71-99 years & 2 & $2.5 \%$ & 2 & 0 & 0 \\
\hline Total & 80 & $100 \%$ & 22 & 54 & 4 \\
\hline
\end{tabular}

Table-2: Distribution of tumor size and metastasis in axillary lymph node in Invasive duct cell carcinoma patients

\begin{tabular}{|c|c|c|c|c|c|c|}
\hline Age group & $\begin{array}{c}\text { No. of } \\
\text { patients }\end{array}$ & Percentage & \multicolumn{2}{|c|}{ Tumor size } & \multicolumn{2}{|c|}{$\begin{array}{c}\text { Metastasis to axillary } \\
\text { Lymph node }\end{array}$} \\
\hline & & & $<2 \mathrm{cms}$ & $>2 \mathrm{cms}$ & No & Yes \\
\hline $1-30$ years & 2 & $2.5 \%$ & $(0 \%)$ & $2(100 \%)$ & $2(100 \%)$ & $0(0 \%)$ \\
\hline $31-40$ years & 18 & $22.5 \%$ & $2(11 \%)$ & $16(89 \%)$ & $10(56 \%)$ & $8(44 \%)$ \\
\hline $41-50$ years & 20 & $25 \%$ & $1(5 \%)$ & $9(95 \%)$ & $13(65 \%)$ & $7(35 \%)$ \\
\hline $51-60$ years & 30 & $37.5 \%$ & $3(30 \%)$ & $27(70 \%)$ & $15(50 \%)$ & $15(50 \%)$ \\
\hline $61-70$ years & 8 & $10 \%$ & $0(0 \%)$ & $8(100 \%)$ & $3(38 \%)$ & $5(62 \%)$ \\
\hline $71-99$ years & 2 & $2.5 \%$ & $0(0 \%)$ & $2(100 \%)$ & $2(100 \%)$ & $0(0 \%)$ \\
\hline Total & 80 & $100 \%$ & $6(8 \%)$ & $74(92 \%)$ & $45(56 \%)$ & $35(44 \%)$ \\
\hline
\end{tabular}


Table-3: Distribution of Estrogen and Progesterone receptors expression in Invasive duct cell carcinoma grade I patients.

\begin{tabular}{|c|c|c|c|}
\hline Age group & IDC Grade I & $\begin{array}{c}\text { Estrogen Receptor } \\
\text { Positive }\end{array}$ & Progesterone Receptor Positive \\
\hline $1-30$ years & 2 & $2(100 \%)$ & $2(100 \%)$ \\
\hline $31-40$ years & 4 & $4(100 \%)$ & $4(100 \%)$ \\
\hline $41-50$ years & 8 & $6(75 \%)$ & $2(33.3 \%)$ \\
\hline $51-60$ years & 6 & $4(66 \%)$ & $0(0 \%)$ \\
\hline $61-70$ years & 0 & $0(0 \%)$ & $0(0 \%)$ \\
\hline $71-99$ years & 2 & $0(0 \%)$ & 12 \\
\hline Total & 22 & 18 & \\
\hline
\end{tabular}

Table-4: Distribution of Estrogen and Progesterone receptors expression in Invasive duct cell carcinoma grade II patients

\begin{tabular}{|c|c|c|c|}
\hline Age group & IDC Grade II & $\begin{array}{c}\text { Estrogen Receptor } \\
\text { Positive }\end{array}$ & Progesterone Receptor Positive \\
\hline $1-30$ years & 0 & $0(0 \%)$ & $0(0 \%)$ \\
\hline $31-40$ years & 14 & $10(71.4 \%)$ & $10(71.4 \%)$ \\
\hline 41-50 years & 10 & $3(30 \%)$ & $0(0 \%)$ \\
\hline $51-60$ years & 24 & $5(20.8 \%)$ & $1(16.6 \%)$ \\
\hline $61-70$ years & 6 & $1(16.6 \%)$ & $0(0 \%)$ \\
\hline $71-99$ years & 0 & $0(0 \%)$ & 15 \\
\hline Total & 54 & 19 & $(16 \%)$ \\
\hline
\end{tabular}

Table-5: Distribution of Estrogen and Progesterone receptors expression in Invasive duct cell carcinoma grade III patients

\begin{tabular}{|c|c|c|c|}
\hline Age group & IDC Grade III & $\begin{array}{c}\text { Estrogen Receptor } \\
\text { Positive }\end{array}$ & Progesterone Receptor Positive \\
\hline $1-30$ years & 0 & $0(0 \%)$ & $0(0 \%)$ \\
\hline $31-40$ years & 0 & $0(0 \%)$ & $0(0 \%)$ \\
\hline $41-50$ years & 2 & $2(100 \%)$ & $0(0 \%)$ \\
\hline $51-60$ years & 0 & $0(0 \%)$ & $1(50 \%)$ \\
\hline $61-70$ years & 2 & $1(50 \%)$ & $0(0 \%)$ \\
\hline $71-99$ years & 0 & $0(0 \%)$ & 3 \\
\hline Total & 4 & 3 & $00 \%)$ \\
\hline
\end{tabular}

Table- 6: Distribution of Estrogen and Progesterone receptors in Invasive duct cell carcinoma patients.

\begin{tabular}{|c|c|c|c|c|c|c|}
\hline \multirow{2}{*}{ Age group } & \multirow{2}{*}{$\begin{array}{c}\text { No. of } \\
\text { patients }\end{array}$} & \multirow{2}{*}{ Percentage } & \multicolumn{2}{|c|}{ Estrogen Receptor } & \multicolumn{2}{|c|}{ Progesterone Receptor } \\
\cline { 4 - 7 } & & Positive & Negative & \multicolumn{2}{|c|}{ Positive } & Negative \\
\hline 1-30 years & 2 & $2.5 \%$ & $2(100 \%)$ & $0(0 \%)$ & $2(100 \%)$ & $0(0 \%)$ \\
\hline $31-40$ years & 18 & $22.5 \%$ & $14(77 \%)$ & $4(23 \%)$ & $14(77 \%)$ & $4(23 \%)$ \\
\hline 41-50 years & 20 & $25 \%$ & $10(50 \%)$ & $10(50 \%)$ & $6(30 \%)$ & $14(70 \%)$ \\
\hline 51-60 years & 30 & $37.5 \%$ & $12(40 \%)$ & $18(60 \%)$ & $8(26 \%)$ & $22(74 \%)$ \\
\hline $61-70$ years & 8 & $10 \%$ & $2(25 \%)$ & $6(75 \%)$ & $2(25 \%)$ & $6(75 \%)$ \\
\hline $71-99$ years & 2 & $2.5 \%$ & $0(0 \%)$ & $2(100 \%)$ & $0(0 \%)$ & $2(100 \%)$ \\
\hline Total & 80 & $100 \%$ & $40(50 \%)$ & $40(50 \%)$ & $32(40 \%)$ & $48(60 \%)$ \\
\hline
\end{tabular}


Table 3 shows comparative decline trend of expression of ER and PR in histological BR grade I patients. Similarly Table 4 and Table 5 show trend of ER and PR expression in histopathological BR grade II and Grade III patients. $40 \%$ of all patients were ER positive and $32 \%$ patients were PR positive.

In all grades of Invasive duct cell carcinoma ER and PR expression was significantly present in early onset age groups as compared to late onset age group. ER and PR expression show decline trend with age ranging from $100 \%$ positive in below 30 years age group to $25 \%$ positive in 70 Years age group as shown in Table 6.

\section{Discussion}

In the present study comprised of 80 cases of invasive duct cell carcinoma, majority of the cases were between 3 ed to $6^{\text {th }}$ decade. Most of patients $(92 \%)$ show tumor size of more than $2 \mathrm{cms}$. Priydarshini Biswal et al [4] Azizum Nisa et al [5] Moses et al [6] and Rashed, Mona $M$ [7] also concluded similar trend in age and tumor size distribution. Sepideh et al [8] show 65\% cases of less than $1 \mathrm{cms}$ tumor size. It is because of western country study where early cancer detection program are run and women are aware of self examination of breast technique.

Present study show $47.5 \%$ ER positive cases and $37.5 \%$ PR positive cases. Study of Priydarshini et al [4] show $40 \%$ ER positive and $32 \%$ PR positive cases. ER and PR expression is greater in histopathological grade I patients as compared to histopathological grade II.

Priydarshini et al [4] Azizumm Nisa et al [5] have shown similar results. No specific trend could be concluded in relation to axillary lymph node metastasis.

Breast carcinoma is a heterozygous malignancy. Its incidence increases with age until menopause and then rise slowly. It reflects superimposition of early and late onset carcinoma breast. Early onset breast carcinoma represents inherited etiology while lat onset breast cancer represents extended influence of cancer promoters to the susceptible mammary epithelium.

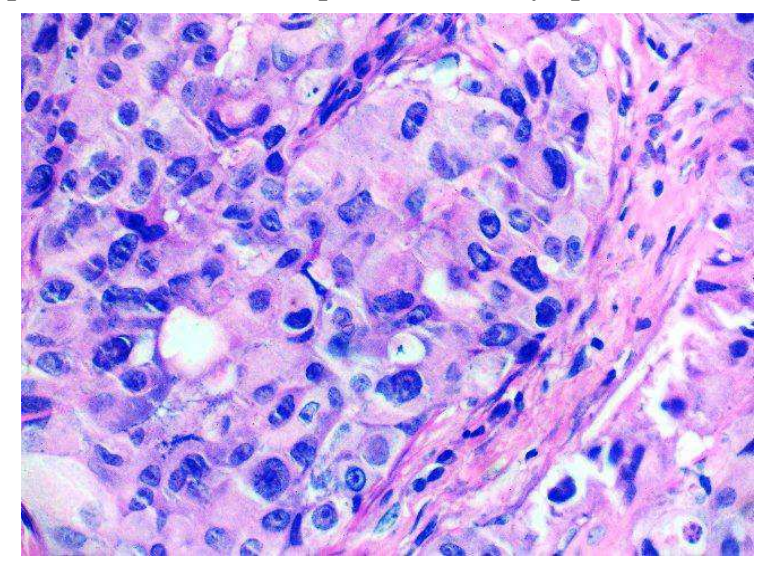

Invasive duct cell carcinoma (H \& E stain)
Expression of ER and PR in normal breast shows gradual increase beginning in $3^{\text {rd }}$ decade to plateau up to $6^{\text {th }}$ decade [10]. Expression of ER and PR correlates well with the incidence of breast carcinoma. It has been postulated that dysregulated ER expression, oxidative stress, and loss of SP1 DNA binding may contribute to breast cancer etiology [11]. Expression of ER gene is inhibited by excessive methylation of ER gene [13]. 5' $\mathrm{CpG}$ island and agents which demethylate the ER gene $\mathrm{CpG}$ island results in functional ER protein [12]. Dysregulated ER expression in premenopausal patients carries strong association with late onset breast cancers. This observation leads to speculate that loss of regulatory mechanism may confer an increased risk of cancer in late onset breast carcinoma [11] [14]. The senescent influence of aging breast leads to decline in ER and PR expression with age, due to methylation of ER alfa gene [14]. In majority of primary breast cancer the ER negative phenotype is not the result of mutation in coding region of ER gene but is due to deficient ER expression at transcriptional level and post transcriptional level [15]. Early breast cancers are thought to largely represent inherited or early life transforming event affecting immature mammary epithelium. Late onset age cancers emerge by an early mutagenic initiating event and then prolong exposure to exogenous or endogenous promoting agents [10]. Thus decline in ER and PR expression with age appears due to methylation of ER alfa gene [15].

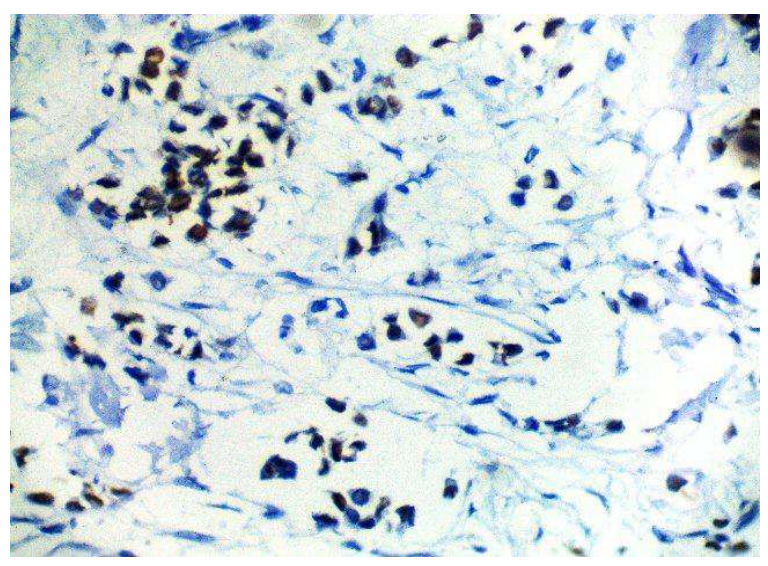

Invasive duct cell Carcinoma (ER Positive) 


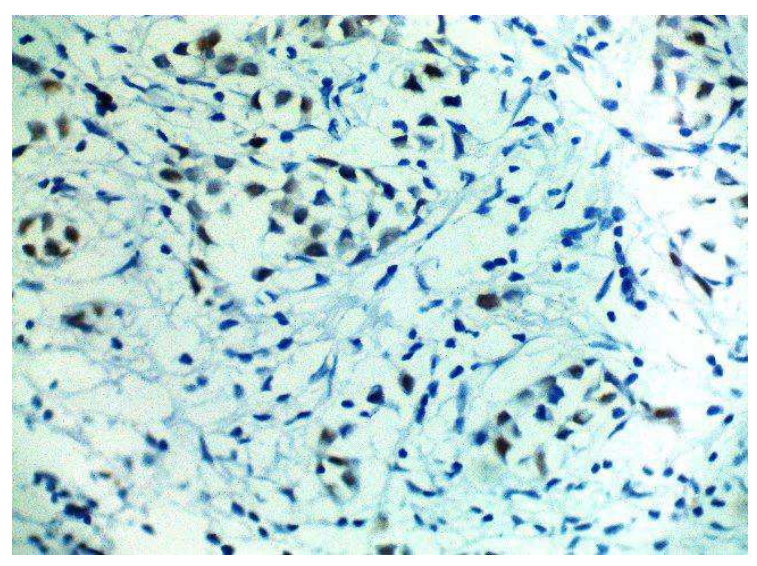

Invasive duct cell Carcinoma (PR Positive)

\section{Conclusion}

Significant correlation of ER and PR expression has been found with age of onset of breast cancer and histology grade. Early onset breast cancer incidence increases up to menopause and then late onset breast cancer rise slowly even when ER PR expression decline. This observation supports the conclusion that biology of breast cancer is age dependent.

Decline in ER expression leads to increase in the risk of breast cancer. Early onset breast cancers would be benefitted by hormone therapy but late onset breast cancers would not respond to hormones because of loss of expression of ER and PR.

In India we have found in majority cases tumor size of more than $2 \mathrm{cms}$ as compares to western studies. Therefore a strong campaign for early detection of breast cancer is recommended. It also calls a need to increase awareness about self examination of breast in women.

Funding: Nil, Conflict of interest: None initiated. Permission from IRB: Yes

\section{References}

1. Ferlay J, Shin HR, Bray F, Forman D, Mathers C, Parkin DM. Estimates of worldwide burden of cancer in 2008: GLOBOCAN 2008. Int J Cancer. 2010 Dec 15; 127(12):2893-917. doi: 10.1002/ijc.25516.

2. Anderson WF, Pfeiffer RM, Dores GM, Sherman ME. Comparison of age distribution patterns for different histopathologic types of breast carcinoma. Cancer Epidemiol Biomarkers Prev. 2006 Oct; 15 (10):1899-905.

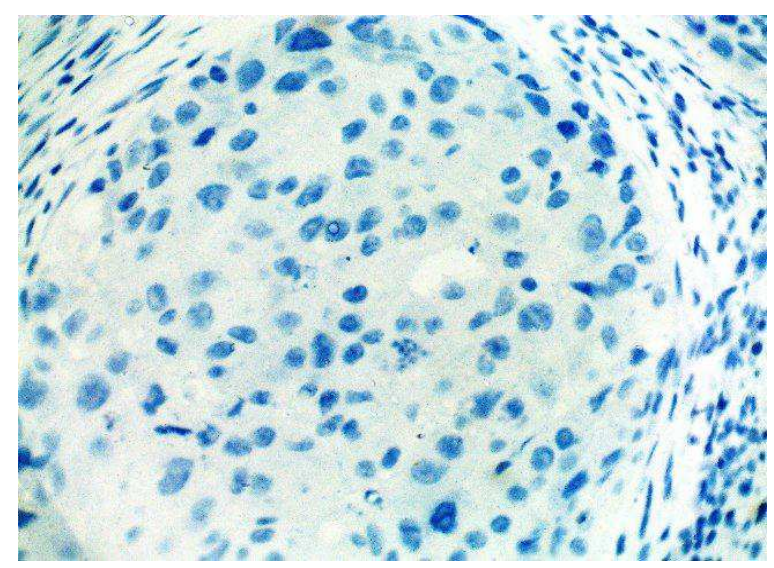

\section{Invasive duct cell Carcinoma (ER Negative)}

3. Quong J, Eppenberger-Castori S, Moore D 3rd, Scott GK, Birrer MJ, Kueng W, Eppenberger U, Benz CC. Age-dependent changes in breast cancer hormone receptors and oxidant stress markers. Breast Cancer Res Treat. 2002 Dec;76(3):221-36.

4. Biswal, P., et al. Correlation of Hormonal Receptors Estrogen Receptor, Progesterone Receptor and Her2/Neu with Tumor Characteristics in Breast Carcinoma: Study of 100 Consecutive Cases. International Journal of Clinical Medicine. 2015, 6, 961-966. doi: 10.4236/ ijcm.2015.612126.

5. Azizun-Nisa, Bhurgri Y, Raza F, Kayani N. Comparison of ER, PR and HER-2/neu (C-erb B 2) reactivity pattern with histologic grade, tumor size and lymph node status in breast cancer. Asian Pac J Cancer Prev. 2008 Oct-Dec;9(4):553-6.

6. Ambroise M, Ghosh M, Mallikarjuna VS, Kurian A. Immunohistochemical profile of breast cancer patients at a tertiary care hospital in South India. Asian Pac J Cancer Prev. 2011;12(3):625-9.

7. Rashed M M et al. The association of Her-2/neu overexpression in relation to p53 nuclear accumulation, hormone receptor status and common clinicopathological prognostic parameters in a series of Egyptian women with invasive ductal carcinoma. Eur J Gen Med. 2007 4(2), 73-79.

8. Rao M, Khan AJ, Moran MS, Hirshfield KM, Ganesan S, Haffty BG, Goyal S. Clinicopathologic presentation of Asian-Indian American (AIA) women with stage 0 , I \& II breast cancer. J Immigr Minor Health. 2011 Feb;13(1):42-8. doi: 10.1007/s10903-0109359-z. 
9. Saadatmand S, Bretveld R, Siesling S, TilanusLinthorst MM. Influence of tumour stage at breast cancer detection on survival in modern times: population based study in 173,797 patients. BMJ. 2015 Oct 6;351: h4901. doi: 10.1136/bmj.h4901.

10. Benz CC. Impact of aging on the biology of breast cancer. Crit Rev Oncol Hematol. 2008 Apr; 66(1): 6574. Epub 2007 Oct 18. doi. org/10. 1016/j. critrevonc. 2007.09.001

11. Post WS, Goldschmidt-Clermont PJ, Wilhide CC, Heldman AW, Sussman MS, Ouyang P, Milliken EE, Issa JP. Methylation of the estrogen receptor gene is associated with aging and atherosclerosis in the cardiovascular system. Cardiovasc Res. 1999 Sep; 43(4):985-91.

12. Rena G, Lapidus, Anne $\mathrm{T}$ Ferguson, et al. Methylation of estrogen and progesterone receptor gene ${ }^{\text {5' }} \mathrm{CpG}$ island correlates with lack of estrogen and progesterone receptor gene expression in breast tumors. Clin Cancer Res. 1996 May;2(5): 805 - 810.

13. Seema A Khan, Mary A M Rogers, Kamal K Khurana, Michael M, Meguid, Patricia J, Numann. Estrogen Receptor expression in benign breast epithelium and breast cancer risk. J of National Cancer Institute. 1998; 90 (1): 37-42. doi: 10.1093/jnci/90.1.37

14. Munjal K, Ambaye A, Evans MF, Mitchell J, Nandedkar S, Cooper K. Immunohistochemical analysis of ER, PR, Her2 and CK5/6 in infiltrative breast carcinomas in Indian patients. Asian Pac J Cancer Prev. 2009; 10(5):773-8.

15. Roodi N, Bailey LR, Kao WY, Verrier CS, Yee CJ, Dupont WD, Parl FF. Estrogen receptor gene analysis in estrogen receptor-positive and receptor-negative primary breast cancer. J Natl Cancer Inst. 1995 Mar 15; 87(6):446-51. doi: 10.1093/jnci/87.6.446

\section{How to cite this article?}

Gupta M, Pal S. Correlation of Expression of ER, PR with the onset age, histopathological grading, size of tumor and metastatic behavior of invasive duct cell carcinoma breast. Int J Med Res Rev 2016;4 (6):1024-1029.doi: 10.17511/ijmrr.2016.106.27. 